\title{
Structurally different rat liver medium-chain acyl CoA dehydrogenases directed by complementary DNAs differing in their 5'-region
}

\author{
Taisuke Inagaki at . Nobuko Ohishi ". Norihiro Tsukagoshi ". Shiguzo U' 'ka ". \\ Sandro Ghisla "and Kunio Yagi

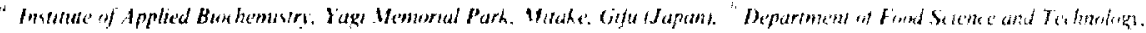

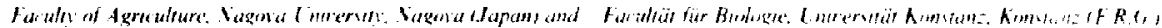

\begin{abstract}
Different forms of rat liver medium-chain acyl CoA dehydrogenase (MCAD) (EC 1.3.99.3) were produced in Escherichia coli carn ing expression plasmids (pRMCADm-1 - 9) differing at the 5 'region of the cDNA. The proteins expressed could be readil extracted from the cells. The protein $(-44 \mathrm{kDa})$ directed by pRMCADm-3 showed the highest activity and was readily purilied to homogeneity. The purified enzy me contained non-covalently bound FAD and was similar to rat liver mitochondrial enzyme in all respects examined. The purified protein $(-45 \mathrm{kDa})$ directed by pRMCADm-1 did not contain FAD and showed no enzsmatic activity. Therefore. the leader peptide disturbs the bindng of FAD to the apoprotein. The purified protein $(-40 \mathrm{kDa})$ directed by pRMCADm-6 did not contain FAD. Thus, the deletion of the $\mathrm{NH}_{2}$-terminal portion of the apoprotein to some extent results in its inability to combine with FAD.
\end{abstract}

\section{Introduction}

Medium-chain acyl CoA dehydrogenase (MCAD) (also called general acy-COA dehydrogenase) (EC 1.3.99.3) is one of the mitochondrial acyl CoA dehydrogenases catalyzing the first step of the B-oxidation oye in the catabolism of fatty acids. The enzyme is a teiramer of four identical $-44 \mathrm{kDa}$ subunits. containing one molecule of non-covalently bound FAD per subunil and catalyzes the dehydrogenation of $C_{3}-C_{1}$ acyl COAs with maximal activity toward the $C_{h}$ one. In this enzvmatic reaction. electron transfer flatoprote $n$ is the obligators natural electron acceptor which reovidize the reduced enzythe [1]. MCAD has been purified t, homogeneity from pig kidney [2]. pig liver [3] bovine liver [4] and rat liver [5]. Like other nudeus-encoded

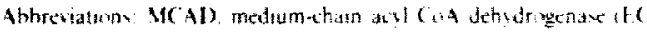

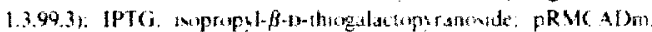

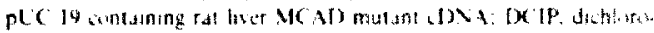

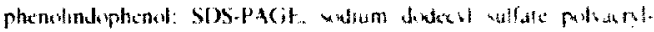
amude gel allectropharewo
}

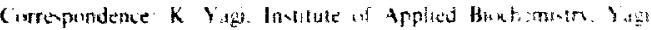

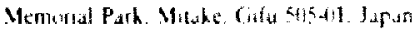

mitochondrial proteins. the enzyme is sinthesized as a precursor hasing a leader peptide $[6-8]$. The cDNAs encodirg the enzyme were isolated from eDNA libraries of rat liver [9.10] and partad :DNA from human liver [11.12] and placenta [12]. Recemls, he isolated a CDNA for MCAD of nearly full length from human piacenta cDNA lihrary [13]. The molecular weighes of the precursor and of the malure enzume of rat liver were colmated to be 46600 and 43700 dation. respectively: thus allowing for a leader peptide of 25 amino acid revidues equaling $290 \%$ daltons $[9]$. The precursor is transferred throigh an energi-dependent mechanism into mitochondria where its leader peptide in deaved by

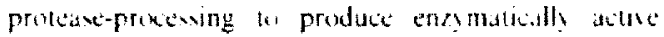
protein $|8|$. The leader peptide is presumably indispensable nor only for importing and processung teps involing milochondrial membrant pasage. but also for atfainment of the three-dimensional utructure of the catalutically inactive precursor From $X$-ras diffaction study pig liver MCAD [14]. the flasin ring of the conzame seem to lie near the $\mathrm{NH}_{2}$-terminal domain of the apoprotein. Therefore. detetion or modification of the $\mathrm{XH}$-terminal portion is expected to give some information on the process of the coenzyme binding for the enchmo achivity. 
in the present studs by deleting some portions of the 5 -regith of the MCAD-encoding cDNA previously isolated [10]. the enzymatically active MCAD and the proteins having a part of the leader peptide or lacking the $\mathrm{NH}_{2}$ terminal region of the matre form were wnthesized in Escherichia coh. We describe here the properties of these MCAD proteins in reiation to the function of this enzyme.

\section{Materials and Methods}

\section{Malleriats}

Enzymes for DNA manipulation, plasmid pUC 19 and M13 DNA sequencing kit were purchased from Takara Shtizo (Kvoto, Japan): $E$. coll JM109. from ToYoBo (Tokyo. Japan): BioCel HTP. BioGel A-5m and horseradish peroxidase-conjugated goat anti-rabbit lgG. From Bio-Rad Laboratories (Richmond. CA. (S.S.): isopropy- $\beta$-1)-thiogalactopyranoside (IPTG), from Wako Pure Chemicals (Oraka. Japan): and $[\alpha-$ ¿PJdCTP. from Amersham International (Buckinghamshire. U.K.). Anti-pig kidney MCAD anliserum was prepared as described previously [7].

\section{Construction of expression plasmid for rat lieer $M C A D$}

A nearly full-length cDNA for rat liver MCAD contained 1230 nucleotides of the coding region and 574 nucleotides of the 3 -noncoding region [10]. The cDNA $\mathrm{Mc}$ isolated coincided with that of Matsubara et al. 19] except for the lacking of the first 30 nucleotides of the precursor. The cDNA was inserted into the EcoRI site of plasmid pLC 19. Expression plasmids for MCAD were constructed in two different ways: (1) the recombinant plasmid was cleaved with Hind III and Sal I. repaired with Klenow fragment and ligated: (2) the recombinant plasmid was cleaved with $\mathrm{Bam} \mathrm{HI}$ and Sph I. treated with exonuclcase III at $37^{\circ} \mathrm{C}$ to delete the $5^{\prime}$-region of the cDNA and aliquots were put into the buffer $(40 \mathrm{mM}$ sodium acetate $(\mathrm{pH} 4.5$ ) containing 100 $\mathrm{mM} \mathrm{NaCl}, 2 \mathrm{mM} \mathrm{ZnCl}$, and $10 \%$ glycerol) 41 ; $\mathrm{s}$ intervals. The deleted plasmids were further digested with mung bean nuclease. repaired with klenow fragment and ligated. The deletion mutants were designated as the $p R M C A D m$ series.

\section{Transformation}

E. coll JM109 was used as host strain for expression of rat liver MCAD. Transformation was carried out as described by Hanahan [15].

\section{Colmon immunoassay}

E. coll JM109 celli transformed with pRMCADm series were spread on LB (Luria-Berlani) agar plates containing $200 \mu \mathrm{g} / \mathrm{ml}$ of ampicillin and $2.5 \mathrm{mM}$ IPTG. The plates were incubated overnight at $37^{\circ} \mathrm{C}$. overlaid with a nitrocellulose membrane (BA 85. Schleicher and
Schüll. Dasicl. F.R.G.) and then incubated at $37^{\circ} \mathrm{C}$ for $6 \mathrm{~h}$. The membranes were treated with chloroform vapor for $15 \mathrm{~min}$ and then incubated overnight at room temperature with $50 \mathrm{mM}$ Tris- $\mathrm{HCl}(\mathrm{pH} \mathrm{7.5)}$ containing 0.15 M KCI. 20 \% fetal calf serum. I mM DNase. $2 \mathrm{mg} / \mathrm{ml}$ of

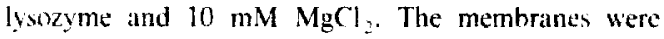
immunostained by treating with the anti-MCAD antiserum followed by horseradish peroxidase-conjugated goat anti-rabbit IgG as described previously [7].

\section{Grouth of bacteria and preparation of cell-free extract}

E. coli IM109 cells carrying expression plasmids were grown aerobically at $37^{\circ} \mathrm{C}$ overnight in $2 \mathrm{ml}$ of LB medium containing $200 \mu \mathrm{g} / \mathrm{ml}$ of ampicillin and 2.5 mM IPTG. The cells were harvested by centrifugation at $8000 \times g$ for 10 min. washed once with $50 \mathrm{mM}$ Tris-HCl (pH 7.4) containing $0.15 \mathrm{M} \mathrm{KCl}$ and resuspended in $500 \mu 1$ of $10 \mathrm{mM}$ Tris-HCl (pH 7.4) containing $1 \mathrm{mM}$ EDTA. The suspension was ruptured by multiple sonication (100 watts, $30 \mathrm{~s}, 6$ times), and cell debris we: removed by centrifugation at $10000 \times g$ for 15 min. The supernatant was used as the cell-free extract.

Purification of rat liver MCAD produced in E. colli carrying the expression plasmid

The cell-free extract $(25 \mathrm{ml})$ prepared as described above from the culture (I I) was fractionated with ammoniam sulfate (20-60\% saturation). The fraction was dialyzed against buffer A (10 mM potassium phosphate ( $\mathrm{pH} \mathrm{7.4)} \mathrm{containing} 10 \%$ glycerol) and applied to a BioGicl HTP column $(2.5 \times 10 \mathrm{~cm})$ previously equilibrated with buffer $A$. The column was washed with buffer $A$ and eluted with a linear gradient of potassium phosphate (10-400 mM. pH 7.4) containing $10 \%$ glyecrol. The fraction containing MCAD. which was detected by immunoblotting using anti-pig kidney MCAD antiserum. was added with ammonium sulfate to $80 \%$ saturation and the precipitate formed was disswlved in $1: m$ of buffer A containing $0.15 \mathrm{M} \mathrm{KCl}$. The sample was subjected to gel filtration on a BioGel A-5m column $(1.0 \times 90 \mathrm{~cm})$ previously equilibrated with buffer A containing $0.15 \mathrm{M} \mathrm{KCl}$. The fraction containing MCAD was pooled and stored in an ice bath until used.

\section{Assay of MCAD antirity}

MCAD activity was determined at $32^{\circ} \mathrm{C}$ by the phenazine methosulfate $(1.5 \mathrm{mM}) /$ dichlorophenolindophenol (DCIP) (0.048 mM) method [2] using n-octanoyl CoA as substrate. One unit of the enzymatic activity was expressed by the amount of the enzyme that reduced $1 \mu$ mol of DCIP per nin.

\section{Sequencing of DNA and protein}

The DNA sequence of plasmids was determined by the dideoxynucleotide chain termination method [16] 


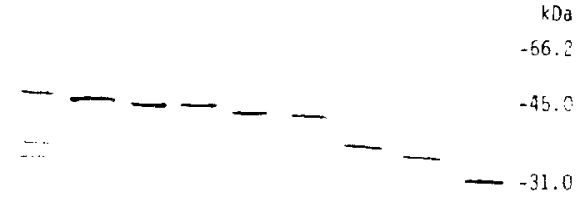

$\begin{array}{llllllllll}0 & 1 & 2 & 3 & 4 & 5 & 0 & \vec{j} & 2 & 9\end{array}$

Fig. 1. Immunotot analysis of telt-free extracts obtained from posilive clones. Cell-frec extracts from positive cioness were subjected so 4-20\% SDS-PAGE: Proteins on the gel were transferred to a nitrocelluluse membrane and the membrane was immunostained using anti-MCAD anliserum. Number of lane represents the clone carrving the following plasmid: 0 . cone carrving DUC 19 alone: 1 . pRMCADm*1: 2. pRMCADm-2; 3. pRMCADm-3: 4, pRMCADm-4: 5. pRMCADm-5; 6. pRMCADm-6: 7. pRMCADm-7; \&. PRMCADm-8: 9. pRMC ADM-9.

using an M13 sequencing kit. The $\mathrm{NH}_{2}$-terminal amino acid sequence of the purified MCAN) was determined in a gas-phase sequenator (Model 470A. Applied Biosystems, Foster City. CA. U.S.A.). High-performance liquid chromatography was carried out with a Shimadzu model LC-4A apparatus to quantitate the phenylthiohydantoin derivatives produced at each cycle of Edman degradation [17].

\section{Other analises}

Immunoblot analysis was carried out using anti-pig kidney MCAD antihody as described by Towhin et al. [18]. Protein content was determined by the method of Lowry et al. [19] using crystaltine bovine serum albumin as standard.

\section{Results}

Expression of cDNA anoding rat liner WCAD in $E$. coll In order to obtain clones produc ag MCAD protein. E. coll JM109 cultures were 1 anstormed with
PRMCADm series and colony immunoassis was carricd out using anti-MCAD antiserum. Nine clones judged positive by immunoassay were isolated. Fig. 1 shows immunoblot analysis of MCAD proteins pro. duced in $E$. coli carrying PRMCADm-1 $~-9$, indicating the production of the anti-MCAD antibady-reaclive proteins with various molecular masses (from 31 to 45 $k D a)$. The extract from $p R M C A D m$-1-bearing bacteria contained two smaller products (35 and $39 \mathrm{kDa}$ ) that reacted with the antiserum. in addition to a $45-\mathrm{kDa}$ protein. More than $90 \%$ of the protein produced by each clone was recovered in the $10000 \times g$ soluble fraction. These proteins were, however. not produced when the clones were grown in the absence of IPTG. The molecular weights of the proteins were relative to the expected length of the CDNA.

Restriction maps of the cDNAs confirmed the stquences of different length in the 5 -region. corresponding to the various molecular weights. Fig. 2 shows the nucleotide sequences of the 5'-region of the CDNAs, where the downward arrows indicate the junction site hetween pUC 19 and the cDNAs of pRMCADm-1. 2. 3. 4,5 and 6 .

Octanoyl CoA-dehydrogenating activities of cell-free extracts from these antibody-positive clones were determined. The extract of $E$. colt carrying pRMCADm-3 showed the highest enzymatic activity, whereas those from exiracts of $E$. coll carrying pRMCADm-4 and PRMCADm-2 wers approx. 90 and $60 \%$, respectively. The extract of $E$. coli hearing pRMCADm 5 showed only merginal activity and the activity in extracts from other clones was helow the detection level (data nox shown).

\section{Purification of rot lieer MCADs produced in $E$. coli}

Among these proteins. those produced in $r$. colt carrying pRMCADm-1. 3 and 6 were purified to compare the characteristics of active and inactive enzumcs.
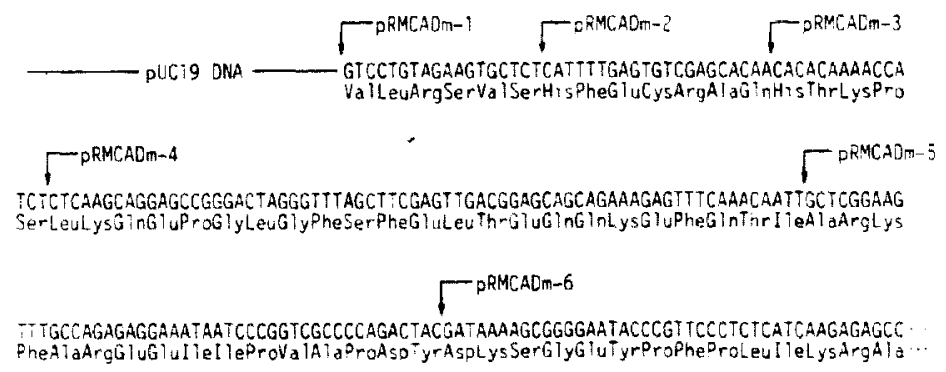

Fig. 2. Nucleceide seguence of 5 -region of expression plasmids pRM( $A 1$ )

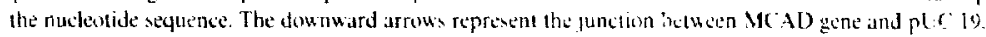




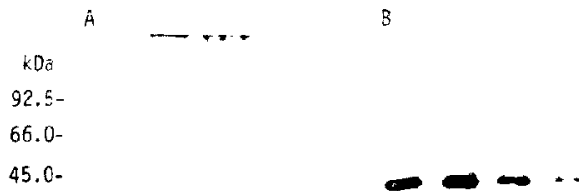

31.0

$21.5-$

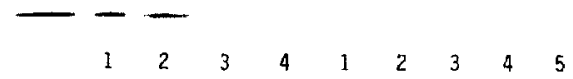

Fig. 3. SDS-PAGE (A) and immunoblot analys : B) of samples ohtained during purification of MCAD produced in $E$ colit carrying pRMCADm-3. Lane 1. cell free extract: 2. ammonium sulfate fracfiol: 3. Biogel HTP fraction: 4. Biogel A-5m fraction: 5. purified MCAD from rat liver mitochondria [10]

A typical result of the purification procedure for the protein directed by pRMCAD- 3 is summarized in Table I. From $485.6 \mathrm{mg}$ protein of the cell-free extract. 3.94 mg of pure MCAD was obtained. Fig. 3 shows the result of sodium dodecyl sulfate polyacrylamide gel electropkoresis (SDS-PAGE) and immunoblot analysis of samples obtained during purification. After hydroxyapatite column chromatography, the protein was almost homogenous; and minor contaminatiag proteins were removed by gel filtration.

The MCAD proteins of $\sim 40$ and $\sim 45 \mathrm{kDa}$ were purified by the same procedure from 216 and $306 \mathrm{mg}$ total protein from $E$. coli harboring pRMCADm- 6 and -1 , respectively. Their yields were $1.2 \mathrm{mg}$ and $0.24 \mathrm{mg}$. respectively.

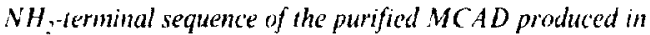
E. coli currying $\mathrm{R} R M C A D \mathrm{Dm}-3$

Fig. 4 compares the amino acid sequence (B) of the $\mathrm{NH}_{2}$-terminal region of MCAD deduced from the DNA sequence $(A)$ with that determined by amino acid sequencing of the purified MCAD $(\mathrm{C})$, indicating correctness of the assumed $\mathrm{NH}_{2}$-terminal sequence.

Properties of the purified MCADs produced in E coll

The absorption spectrum of the purified MCAD from pRMCADm-3-infected cells exhibited muxima at
PUC19 ONA
PRMCADM-3
(A) atgacCatgattaCgagcttgcacaCaAaACCATCtCtCAag $\ldots$
(B) MetThrMetlleThrSerLeuH:sThrLysProSerLeuLys...

\author{
ThrLysProSerLeulys $\cdots$ \\ 1
}

Fig. 4. Nucleotide and deduced amino acid sequences of 5 -region of plasmid pRMCADm-3 and $\mathrm{NH}_{2}$-terminal sequence of purified MCAD. The upward arrow represents the cleavage site between the leader peptide and the mature enzyme [9]. A. nucleotide sequence: $B$. deduced amino acid sequence from DNA sequence: $\mathrm{C}$. $\mathrm{NH}_{2}$-terminal sequence of the purified MCAD determined by chemical analysis

275. 370. and $445 \mathrm{~nm}$ at pH 7.4 (Table II). Fig. 5 shows the visible absorption spectrum. which coincides with that of MCAD purified from rat liver mitochondria. The properties of the enzyme purified from pRMCADm-3-infected cells fairly agree with those of MCAD from rat liver mitochondria (Table II). FAD was released by treating the purified MCAD with $5 \%$ trichloroacetic acid. indicating that it is non-covalently

\section{TABLE II}

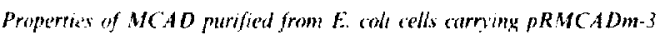
and of MCAD from rat liver mitochondria

\begin{tabular}{|c|c|c|}
\hline Property & $\begin{array}{l}\text { MCAD produced in } \\
\text { E. coll /pRMCADm-3 }\end{array}$ & $\begin{array}{l}\text { MCAD from } \\
\text { rat liver } \\
\text { mitochondria }\end{array}$ \\
\hline Sulsunit (kDa) & $\begin{array}{l}43^{\prime \prime} \\
438^{\circ}\end{array}$ & $\begin{array}{ll}45 \\
43.74\end{array}$ \\
\hline Spectral maximia (nom) & $275 / 370 / 445$ & $271 / 370 / 445$ \\
\hline $\begin{array}{l}\text { Ratio of absorhance } \\
\text { maxima }(275 / 370 / 455)\end{array}$ & $11.3 / 0.7 / 10$ & $6.3 / 0.75 / 1.0$ \\
\hline $\begin{array}{l}\text { Specific activity } \\
\text { (uniss/mg protein) }\end{array}$ & 1113 & 11.9 \\
\hline 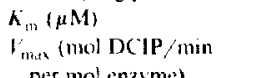 & 1.4 & 4.0 \\
\hline per mol enzyme) & 32.3 & 27.2 \\
\hline
\end{tabular}

From Ret. 5

"Estimated hy SDS-PAGF in the present studs

Calculated from nucleotide sequence in the present sudy

"From Ret. ?.

Measured at ph 7.4 .

' m-Oetanowl CoA was used as substrate

TABLE I

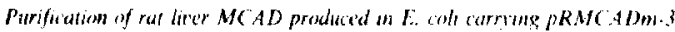

\begin{tabular}{|c|c|c|c|c|c|}
\hline Procedure & $\begin{array}{l}\text { Total } \\
\text { protein } \\
\text { (mg) }\end{array}$ & $\begin{array}{l}\text { Totil } \\
\text { activity } \\
\text { (units) }\end{array}$ & $\begin{array}{l}\text { Specific } \\
\text { activity } \\
\text { (units/mg) }\end{array}$ & $\begin{array}{l}\text { Yield } \\
(\%)\end{array}$ & $\begin{array}{l}\text { Purification } \\
\text { (fold) }\end{array}$ \\
\hline Cetl-free extracl ${ }^{*}$ & 485.6 & 912 & 0.19 & 160 & 1 \\
\hline $20-60^{\prime \prime} \mathrm{r}\left(\mathrm{NH}_{4}\right)_{2} \mathrm{SO}_{4}$ & 314.4 & 132.8 & 0.42 & 146 & 22 \\
\hline HioGel НTP & 17.6 & $\$ 2.8$ & 3.57 & 69 & 18.8 \\
\hline BioGel A-5m & 3.94 & 40.6 & 10.30 & 45 & 54.2 \\
\hline
\end{tabular}

"From 11 of culture (6 g oi celli) 


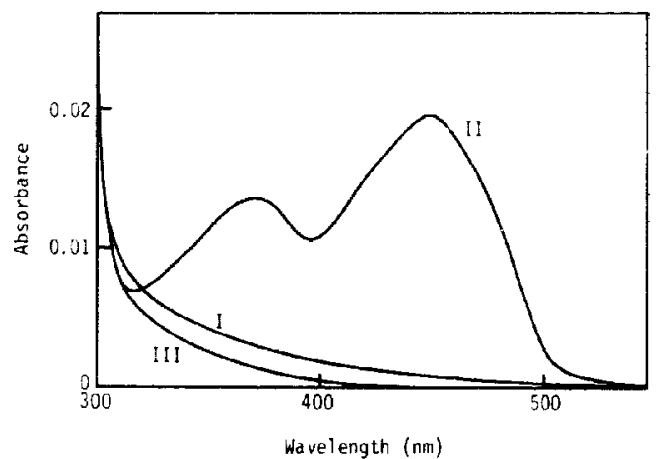

Fig. 5. Visible shsorption spectra of purified MCADs produced in E. whl carrying pRMCADm-1, -3 and -6. The purified MCAD $(0.15 \mathrm{mg} / \mathrm{ml})$ was dialyzed against $50 \mathrm{mM}$ potassium phosphate buffer ( $\mathrm{pH} 7.4)$ and its spectrum was measured. I. MCAD produced with pRMCADm-1: II. that with pRMCADm-3; III, that with pRMCADm-6.

bound. On the other hand. the purified proteins directed by pRMCADm-1 and pRMCADm-6 did not contain FAD as can be seen in Fig. 5 and showed no enzymatic activity. Also, no activity was observed upon addition of FAD.

\section{Discussion}

Precursor proteins including a leader peptide have been reported to form an insoluble material termed 'inclusion body' [20] when synthesized in $E$. coli. On the other hand, precursors without a leader peptide. such as those of cytosolic proteins, are expressed in a soluble form in the bacteria [21,22]. In the present study, the rat liver MCAD proteins synthesized in $E$. coli were recovered in the $10000 \times g$ soluble fraction. This is interpreted as indicating the deletion of amino acids (more than 10 residues) from the leader peptide. This also agrees with the results of Jaussi et al. [23], who reported that the insoluble precursor of chicken mitochondrial aspartate aminotransferase synthesized in $E$. coli was cenverted to a soluble enzyme upon removal of the leader peptide.

The protein synthesized in pRMCADm-3-infected $E$. coli was expected to be a hybrid protein, since the plasmid contained information for eight extra amino acids of the $\mathbf{N H}_{2}$-terminal region as shown in Fig. $\mathbf{4}$. However, in the $\mathrm{NH}_{2}$-terminal sequence obtained from the purified protein. this extra peptide was found to be absent. This is assumed to be due to the action of bacterial proteinases.

The protein from pRMCADm-3 was purified to homogeneity by a simple procedure using solely hydroxyapatite column chromatography and gel filtration. This protein contained non-covalently bound FAD. and its abso ption spectrum in the visible region fairly agreed with those of MCAD from rat liver mitochondria [2-5]. This indicates that FAD in the bacteria is readily available and binds to the apoprotein either during or after the folding of the polypeptide chain. resulting in a stable form. The binding of prosthetic group to apoprotein synthesized in $E$. coli was also reported in the cases of rat liver NADPH-cytochrome $P-450$ oxidoreductase [24] and of rat liver aspartate aminotransferase [22].

The enzymatic properties of the purified MCAD from pRMCADm-3-bearing bacteria were fairly similar to those of the enzyme from rat liver mitochondria. It should be pointed out that activity determinations with MCAD are subject of considerable variation duc to difficulties inherent to the assay systems. as noted by several authors [2.25]. The differences to be seen in Table II. in particular that in $K_{\mathrm{m}}$. might not be significant. However, this problem should await further investigation.

The MCAD purified from the ceils carrying pRMCADm-1 did not contain FAD and showed no activity. even in the presence of added FAD. Since the protein directed by pRMCADm-1 has a substantial portion of the leader peptide, the binding of the flavin coenzyme to the apoprotein is probably prevented by the leader peptide.

Further, the MCAD protein purified from $\mathrm{PRMC}$ ADm-6-bearing cells did not contain any FAD and showed no enzymatic activity, even in the presence of FAD. The crystallographic structure of MCAD from pig liver mitochondria made by Kim and $\mathrm{Wu}_{\mathrm{u}}$ [14] showed that this enzyne consists of three domains. The $\mathrm{NH}_{2}$-terminal domain is composed of 6 a-helices, the middle one is packed with $\beta$-sheets. and the C-terminal one is composed again of $6 a$-helices, and the flavin ring lies in the crevice between the first two domains. From the three-dimensional structure, it is apparent that the $\mathrm{NH}_{2}$-terminal portion of the polypeptide participates in the flavin binding. The deletion of 42 amino acid residues in the protein direc:-d by pRMCADm- 6 implies the absence of the first helix of the $\mathrm{NH}_{2}$-terminal portion [14]. Apparently, the absence of this region results in the failure in forming the functional three-dimensional structure of the mature enzyme. which makes the apoenzyme unable to combine with $\mathrm{FAD}$.

\section{References}

1 Crane. F.L., Mii. S., Hauge. J.G. Green. D.E. and Beinert. H. (1956) J. Biol. Chem. $218.701-716$.

2 Thorpes. C.. Matthews. R.G. and Williams. C.H. Jr. (1979) Biochemistry 18, 331-337.

$3 \mathrm{Kim}$. J.J. P. Vollmer, S H. and Freman F.E (1984) J Biol Chem. 259. 3318-3319

4 Dommes. V. and Kunau, W-H. 1984) J. Biul. Chem. 259. 17891797. 


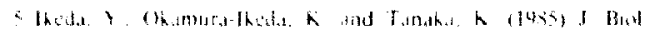

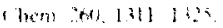

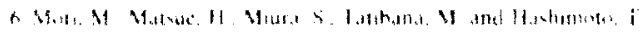

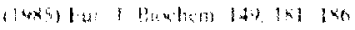

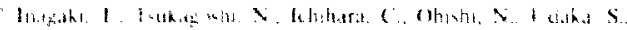

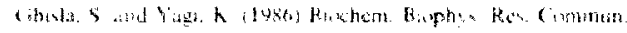
13. 104450.90.

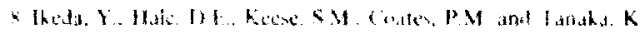

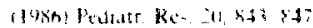

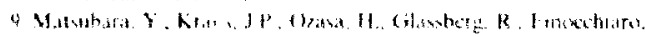

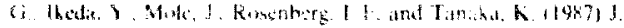

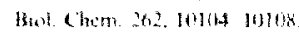

10 Inagah. 1 . Ohushi N.. Rarted. 1. Frank. R.W. Ghela. S Trukaguh. N. ldika. S. and Ydgi, K. $(1987)$ Bionem. Int. 15. $1051-1456$

11 Matcuhara Y. Krius IP. Young-Feng T.I... Francke. I .. Ro-

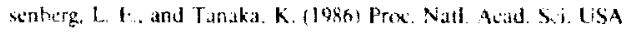
X3. 654,654 ?

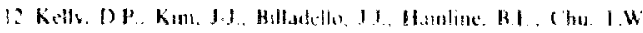

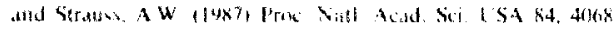
$4,7+2$

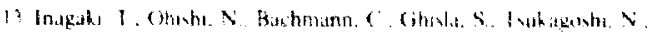

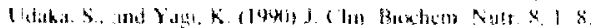

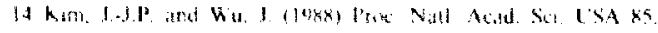
$\{0,7)$ (xis)

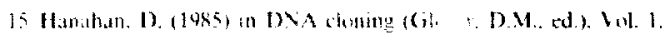

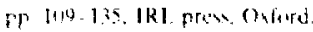

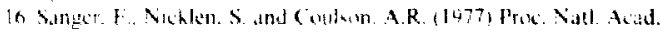

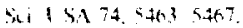

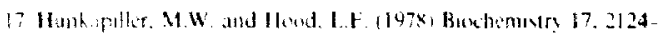
I13.3.

18 Tumbin. H. Siaktelm. T and Gurdon. 1. (1979) Proc. Natl. Acad. Sid 1 S1 $74,43511.4354$

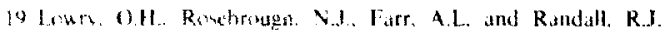
119511 J. Bint (hem 193.265.275

3) Horrs, T.J.R (1983) in (ientic rngintermg (Willamun. $R$. ed.). Vid. 4. pp. 127-15.5. Academic Pren, London.

21 Tanizawa. Y. Kinhi. F., Kanemer, T. and Nakazaua. A. (1987) J. Bikehem. 101. 1289-1296

22 Ilorio. Y.. Tanaka. T. Taketoshı, M.. Nagavinma. F. Tanase. S. Morina, Y. and Wada. H. (1988) J. Birkhem. 1013. 797-8014.

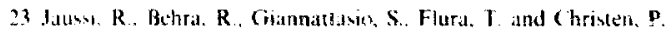
1198?), Binl Chem. 20. 12434-12437.

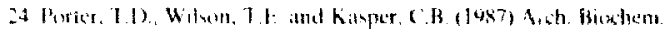

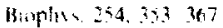

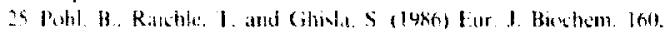
In 115 